\title{
Monetary Policy and Stock Markets Evidence from EU Countries
}

\author{
Ovidiu Stoica and Delia-Elena Diaconașu
}

"Alexandru Ioan Cuza" University, Iasi, Romania

\begin{abstract}
The analysis of monetary policy impact - via interest rate as instrument of intervention - on the evolution of stock market prices has gained more popularity during the current crisis due to the accumulation of financial imbalances. This article investigates the impact of monetary policy on equity indexes in European Union countries from January 2000 to February 2012, using cointegration and Granger causality tests. The results reveal the existence of long and short term relationship between stock prices and interest rates. We also find that on the long-run the comovement between interest rates and stock prices are stronger during crisis period, when compared with entire period.
\end{abstract}

Keywords: stock prices, short-term interest rate, EU, Granger causality, financial crisis.

\section{Introduction}

Lately, the whole EU financial stability has strengthened, but continues to record significant challenges in terms of increased sovereign risk in some countries with a difficult situation regarding the sustainability of public finances and in terms of maintaining vulnerabilities in some financial sectors. EU authorities' reaction on improving economic governance system has been creating a permanent mechanism to support financial stability and implementing new micro and macro-prudential financial supervision architecture.

The main objective stipulated in the status of all central banks from EU countries is to ensure price stability. Moreover, the recent crisis embodied the fact that extending the mandate of the central banks' price stability to financial system should be taken into account. Several arguments in this regard are: the fact that central banks benefit of essential expertise in analyzing financial systems from a global perspective and have appropriate incentives to mitigate systemic risk ex ante; the harmonization of national macro-prudential framework through a coordinated approach at European level would facilitate a more clear establishment of responsibilities and improving governance. The cons are mainly: the fact that is difficult to determine the right time for a proactive response of monetary policy; the existence of a risk of overload objectives; the non-linearity and unpredictability of financial crisis.

The transmission channels of monetary policy in UE countries are influenced by certain factors like low or high level of monetization, the structure of the financial system (bank oriented or financial market oriented financial system, the preponderance of foreign capital in some countries), that influence the effectiveness of monetary policy on capital markets.

Copyright (C) 2012 Ovidiu Stoica and Delia-Elena Diaconașu. This is an open access article distributed under the Creative Commons Attribution License unported 3.0, which permits unrestricted use, distribution, and reproduction in any medium, provided that original work is properly cited. Contact author: Ovidiu Stoica Email: ostoica@uaic.ro 
The purpose of our paper is to analyze the relationship between monetary policy and stock markets indices in European Union, related to the financial crisis from 2008. We conducted our research for several reasons. First, the recent crisis highlighted the necessity to place more emphasis on the objective of maintaining financial stability by central banks. Second, even if central bank monitors the developments in financial markets, in the literature does not exist consensus regarding the role of monetary authorities in the management of asset prices developments. In this regard, a number of authors argue that central bank should not take into consideration asset prices developments (Assenmacher-Wesche and Gerlach, 2008; Hunter et al., 2005), while other authors (Bordo and Jeanne, 2002) argue that monetary policy should respond to changes in stock prices. Third, the EU economies are closely interrelated in terms of trade relations and geographic proximity.

Our findings suggest that there exist a longrun relationship between interest rates and stock prices, and this is strengthening during the crisis period. In terms of causal relationship, the comovement between stock and money markets is lower during the crisis periods than during those that are tranquil

The rest of the paper proceeds as follows. Section 2 briefly surveys the major contributions of the literature review. Section 3 explains our data set and the methodology used. Section 4 discusses the empirical results. Section 5 brings the main conclusions.

\section{Literature Review}

The evolution of stock prices presents important implications upon financial stability, because speculative bubbles may degenerate into a financial crisis. Central banks monitors the developments in financial markets, but in the literature does not exist a unanimous consensus regarding the role of monetary authorities on stock market.
A number of authors argue that central bank should not take into consideration asset prices developments. Among them, are found Assenmacher-Wesche and Gerlach (2008) who shows that setting the monetary policy's response to asset price movements can generate higher losses than those resulting from a possible explosion of asset bubbles. The same position is adopted by Illing (2006) who argues that a possible central bank intervention on asset markets, through injecting liquidities, may increase financial instability. Hunter et al. (2005) argue that monetary authorities are unable to identify financial imbalances early enough and with the necessary degree of comfort to take remedial measure, because trying to respond to financial imbalances may increase the volatility of the economy. In addition, Bullard and Schaling (2002) share views on the fact that including stock market variables in monetary policy reaction functions might at best be irrelevant for the overall economic outcome, but might cause considerable harm in the worst case. In contrast, Bordo and Jeanne (2002) argue that monetary policy should respond to changes in stock prices because drastic changes in these have strong and persistent negative effects on output and employment.

The causal dynamics between interest rates and asset returns have become the subject of intensive research by financial economists to explain asset prices. In this regard, changes in the interest rate affects the investors required rate of return and therefore stock prices, resulting that interest rate and stock prices should have a negative relationship. The responses estimation of asset prices in changes of monetary policy is hampered by the endogeneity of political decisions and by the fact that both interest rates and asset prices are influenced by many variables (Rigobon and Sack, 2004). Moreover, Kaul (1987) argues that the nature of the relationship varies in a systematic manner depending on whether money supply is countercyclical or procyclical. However, the general conclusion is that stock markets are sensitive to unexpected changes in monetary 
policy and the sensitivity depends by the economy's particularities.

Hussain (2010) highlights the fact that monetary policy decisions have a significant and immediate influence on volatility and stock index returns in both European (France, Germany, Switzerland, United Kingdom) and the U.S. markets. On the same level of intraday data is situated the research realized by Farka (2009) which provide a similar conclusion, noting that volatility depends on the type and timing of monetary policy shocks. Andersson (2010) analyzes bond and stock market volatility reactions in euro area and U.S. under the impact of monetary policy decisions and he discovers a significant growth of intraday volatility as following monetary policy decisions of the two central banks.

Bjorland and Leitamo (2009) analyze the interdependence between U.S. monetary policy and the development of S\&P500 stock market index, finding a great interdependence between the interest rate setting and real stock prices. Vithessonthi and Techarongrojwong (2012) demonstrate that changes in the monetary policy have an impact on stock prices and that these respond negatively to the expected change in the repurchase rate in the context of Thailand. On this topic there exist numerous studies which embrace the idea that monetary policy actions are associated with changes in stock prices (Bredin et al., 2007; Konrad, 2009). In contrast with the result obtained for U.S. and Thailand, the empirical findings of Bohl et al. (2007) show a generally low relationship between German market index return and interest rates on short term, in 1985-1998. However, as in the United States, Bundesbank reacted to stock market crash from 1987 by relaxing monetary policy conditions. Also referring to Germany and in addition to U.K., Corallo (2006) finds that an unexpected increase in the interest rate depresses equity prices, but this relationship is not statistically significant.
Li, Ișcan and $\mathrm{Xu}$ (2010) find that in Canada, the immediate response of stock prices to an internal contradictory monetary policy shock is low and on short time, while in the United States, the immediate response to a similar shock in stock prices is more significant and its dynamic response is relatively long. Also, Ioannidis and Kontonikas (2008) investigates the impact of monetary policy on index returns in 13 OECD countries during 19722002 period, and the results indicates that a change in monetary policy significantly affect index returns. Going further with the analysis, Pennings et al. (2011) estimate the impact of monetary policy upon exchange rates and stock markets for eight open economies, showing that, on average, in these countries, an increase by one percentage point in official interest rates determines an appreciation on exchange rate by $1 \%$ and a decrease, by the same percentage, of stock market indices.

The recent financial crisis has demonstrated that the potential economic and social costs of financial instability can be devastating. The existing consensus before triggering the crisis in accordance to which the monetary policy should take asset prices into account only if these affect inflation, is challenged. In the modern literature we find few studies regarding the role of stock markets in central bank policy in non-crisis periods, particularly for the European Central Bank. A representative study is realized by Botzen and Marey (2010), who analyze the influence of stock price developments upon the ECB's monetary policy over the period 1999-2005. The authors find that the evolution of stock prices has exerted influence on the key ECB interest rates before the crisis. Cassola and Morana (2004) emphasized the fact that stock prices seem to hold an important role in the transmission mechanism in the euro area and that a monetary policy focused on long-term price stability can also ensure the stability of the stock market. 
Aiming the long-term synergy between price stability and financial stability, monetary policy should take into account asset price developments, but should not be overlooked that the impact on capital market of the instruments used depends on other factors like: the openness of the economy, capital market importance within financial system, credibility and transparency of monetary authorities.

\section{Data and Methodology}

\section{Data}

The data consists in short-term interest ratemonthly data and stock price index-monthly data covering the period January 2000 February 2012 for all 27 EU members, namely: Austria, Belgium, Bulgaria, Cyprus, the Czech Republic, Denmark, Estonia, Finland, France, Germany, Greece, Hungary, Ireland, Italy, Latvia, Lithuania, Luxembourg, Malta, the Netherlands, Poland, Portugal, Romania, Slovakia, Slovenia, Spain, Sweden, and the United Kingdom. We choose money market interest rate because the deposits represent an alternative to portfolio investment. The data were collected from Eurostat Database.

In order to investigate whether or not the causality between interest rate and stock prices changes over time, we construct a number of time series samples from our data set: the entire period, and a post crisis subperiod (July 1, 2007 to February 29, 2012).

\section{Methodology}

The first step is to test the stationarity of the data series. In this regard we performed the Augmented Dickey-Fuller (ADF) and Kwiatkowski-Philips-Schmidt-Shin (KPSS) tests .

We then perform Engle Granger Test to see if the components of a $n \times 1$ vector time series $Y_{t}$ are co-integrated of order $(d, b)$ which we will denote by $Y_{t} \approx C I(d, b)$, with $b, d \in \mathrm{N}_{+}$.

If the test suggests the presence of cointegration between the variables we then perform the Johansen-Juselius likelihood cointegration tests to identify the existence of $r$ co-integrating vectors.

$$
\begin{aligned}
& \lambda_{\text {trace }}(r)=-2 \log (Q)=-T \sum_{i=r+1}^{n} \log \left(1-\hat{\lambda}_{i}\right) \\
& \lambda_{\max }(r, r+1)=-2 \log (Q)=-T \log \left(1-\hat{\lambda}_{r+1}\right)
\end{aligned}
$$

Where $i=r+1, \ldots, n$, are the $(n-r)$ smallest squared canonical correlations, $r=0,1,2, \ldots, n$ -1 , and $\lambda_{\text {trace }}(r)=0$, when all $\hat{\lambda}_{i}=0$. The first trace test is testing the hypothesis that there are at most $r$ distinct co-integrating vectors against a general alternative, while the second test is used to compare the null hypothesis of $r$ co-integrating vectors against the alternative of $(r+1)$ co-integrating vectors. The first test is preferred to the second one because it is more powerful (Alagidede et al., 2011).

Depending on the results of the cointegration test we applied the unrestricted VAR - if there is no co-integration between the two variables - or the Vector Error Correction, otherwise.

Let $\mathrm{Y}_{\mathrm{t}}$ be a VAR model of order $\mathrm{p}$ with the following standard representation:

$Y=\Phi(L) Y_{t-1}+\varepsilon_{t}$

Where the vector Y describes the vector of the two endogenous variables, which is given by short-term interest rate and the stock prices. $\Phi(\mathrm{L})$ is a lag polynomial of order $\mathrm{p}$.

The lag length of unrestricted VAR or VECM is determined by the use of information criteria - Akaike's information criteria (AIC) of the underlying un-differenced VAR model. 
Granger causality measures are constructed to explore the causal relationship between two time series. The idea of Granger causality is that a time series Xt Granger-causes another time series Yt if Yt can be predicted better by using the past values of Xt than by using only the historical values of Yt. Testing causal relations between the two series can be based on the following bivariate autoregression:

$$
\begin{aligned}
& Y_{\mathrm{t}}=\alpha_{0}+\sum_{k=1}^{n} \alpha_{\mathrm{k}} Y_{\mathrm{t}-\mathrm{k}}+\sum_{\mathrm{k}=1}^{\mathrm{n}} \beta_{\mathrm{k}} \mathrm{X}_{\mathrm{t}-\mathrm{k}}+u_{\mathrm{t}} \\
& \mathrm{X}_{\mathrm{t}}=\gamma_{0}+\sum_{k=1}^{n} \gamma_{\mathrm{k}} Y_{\mathrm{t}-\mathrm{k}}+\sum_{\mathrm{l}_{\mathrm{k}-1}}^{n} \theta_{\mathrm{k}} X_{\mathrm{t}-\mathrm{k}}+u_{\mathrm{t}}
\end{aligned}
$$

Where, ${ }^{\alpha} \alpha_{0}$ and $\gamma_{0}$ are constants, $\alpha_{k}, \beta_{k}, \gamma_{k}$, $\theta_{\mathrm{k}}$ are parameters, and $\mathrm{u}_{\mathrm{s}}$ are uncorrelated disturbance terms with zero means and finite variances. The null hypothesis that $\mathrm{Xt}$ does not Granger-cause Yt is rejected if the $\alpha_{k}$ coefficients in the first equation are jointly significantly different from zero using a standard joint test. Similarly, Yt Grangercauses $\mathrm{Xt}$, if the $\mathrm{Y}_{\mathrm{k}}$ coefficients are jointly different from zero in the second equation. A bi-directional causality (or feedback) relation exists if both the $\alpha_{k}$ and $\gamma_{k}$ coefficients are jointly different from zero.

We performed the causality test through a VECM approach if the set of variables are cointegrated (Alagidede et al., 2011).

\section{Empirical Results}

First, the ADF unit root and the KPSS stationary tests were employed (the results are not given here but are available by the authors upon request) in order to determine the order of integration. Stationarity hypothesis is rejected for in all cases, ADF results confirming that all series are integrated of first order. This is confirmed also through the KPSS test.

Since all the variables have the same order of integration we proceed by employing the Engle-Granger test. If interest rates and stock prices are co-integrated, then an error correction term should be included in the bivariate autoregressions. We estimate the error correction term using the residual from a regression (OLS) of interest rates series and stock prices series and then we apply the ADF test to see if the residuals are stationary. If the residuals of the regression are stationary, the variables are co-integrated and the resulted equation is a co-integrating relationship (long-term equilibrium relationship). Data from the output table are then compared with critical values from Engle-Granger Residual Based Table Test. The results from comparing the two tables highlight that the residuals are stationary only in the cases of Netherlands, France, Finland and Italy, which implies cointegration existence in the entire period (the results are not given here but are available by the authors upon request). Regarding the second sub-period, the null hypothesis of no co-integration between the variables is rejected in more states, i.e. Netherlands, Austria, Belgium, Romania, Cyprus, France, United Kingdom, Finland, Ireland, Italy, Luxembourg, Malta, Portugal, Latvia and Slovenia. The overall results, therefore, indicate that there is a long-run equilibrium relationship among the two variables only in the reminded countries. This establishes the fact that when markets react actively, interest rates affect the mentioned capital markets in long term. This is also supported by Adam and Tweneboah (2008), who established that long-run relationship existed between interest rates and stock prices in Ghana and by Pal and Mittal (2011) in the case of India. In the rest of the cases the two variables are not co-integrated. In the same sense, Korkeamäki (2011) find that while stock returns in most countries in the Western Europe were negatively correlated with interest rate changes prior to the euro, that correlation has disappeared since 1999.

The previously test informed us on the existence of long-term links between variables in several EU countries, and for finding the number of vectors in this test we perform Johansen Co-integration test on 
interest rates and price indexes in the two periods, as presented in Table 1 and Table 2, respectively. However, since we took into consideration countries pairs it is obvious that there can not be more than one cointegration vector between the analysed variables.

The finding are consistent with the results of past literature that in some countries the no long-run co-integration relationship between interest rate and stock prices exist (Korkeamäki, 2011), while in other cases the long-run co-integration between the two variables exist (Adam and Tweneboah, 2008; Pal and Mittal, 2011). However, when we took into consideration the post-crisis period, the situation is different, highlighting the fact that this dynamics exist amongst the two variables in twenty countries. This means that long-run linkages among the interest rates and stock prices are more inclined to occur during the crisis period than in calm ones. These results might be due to the contagion or spillover between the two variables during the crisis and to the investors' uncertainty regarding the unfavorable macroeconomic environment. In addition, this findings support Lin's (2012) research, which emphasize that the comovement between macroeconomic variables and stock prices becomes stronger during crisis periods than during tranquil ones.

Table 1. Johansen Test, January 2000 - February 2012

\begin{tabular}{|l|c|c|c|}
\hline Countries & r & Trace & Critical value 5\% \\
\hline Netherlands & 1 & 8.229761 & 3.841466 \\
France & 1 & 7.332882 & 3.841466 \\
Finland & 1 & 6.506546 & 3.841466 \\
Italy & 1 & 4.267431 & 3.841466 \\
\hline
\end{tabular}

Table 2. Johansen Test, July 2007 - February 2012

\begin{tabular}{|l|c|c|c|}
\hline Countries & r & Trace & Critical value 5\% \\
\hline Austria & 1 & 4.617548 & 3.841466 \\
Belgium & 1 & 7.025928 & 3.841466 \\
Bulgaria & 1 & 4.382167 & 3.841466 \\
Cyprus & 1 & 4.772490 & 3.841466 \\
Estonia & 1 & 8.367395 & 3.841466 \\
Finland & 1 & 4.980002 & 3.841466 \\
France & 1 & 5.725781 & 3.841466 \\
Ireland & 1 & 9.507788 & 3.841466 \\
Italy & 1 & 5.429534 & 3.841466 \\
Latvia & 1 & 3.914111 & 3.841466 \\
Lithuania & 1 & 5.109739 & 3.841466 \\
Luxembourg & 1 & 5.052526 & 3.841466 \\
Malta & 1 & 5.886290 & 3.841466 \\
Netherlands & 1 & 6.290328 & 3.841466 \\
Poland & 1 & 12.23159 & 3.841466 \\
Portugal & 1 & 4.629525 & 3.841466 \\
Romania & 1 & 7.618714 & 3.841466 \\
Slovenia & 1 & 4.796560 & 3.841466 \\
Sweden & 1 & 11.28390 & 3.841466 \\
United Kingdom & 1 & 4.473470 & 3.841466 \\
\hline
\end{tabular}


We will employ standard Granger causality test for the variables that don't have cointegrated relationship, and Granger causality test within the framework of a vector error correction model if the set of variables are co-integrated, for both analyzed periods. Before employing Granger causality test, we determined the optimum lag order suggested by Akaike Information Criteria and the results are reported in Table $\mathrm{A} 1$ in Appendix A for both periods. In the tables below we will show only the causal relationship between the analysed variables that are statistically significant at 5\%. We will note with SP the stock price and with IR the interest rate.

The results of Table 3 shows the causality results for the full sample period, in which it can be observed that the direction of causation: is bi-directional for Germany, Sweden, France, Italy and Estonia, is unidirectional from the stock to the money market for Greece, Austria, Belgium, Cyprus, Denmark, United Kingdom, Ireland, Luxembourg, Portugal, Czech Republic, Slovenia and Spain, and is non-causal for Netherlands, Romania, Hungary, Malta, Bulgaria, Finland, Lithuania, Latvia, Poland and Slovakia. Therefore, the results suggest that there is more evidence that the causation runs from stock market to money market than the reverse. These results are in line with the Bhattarai and Joshi (2009), study which finds that there is lack of relationship in the short-run between interest rate and stock market in Nepal, and with Pal and Mittal (2011) study which reveals that interest rates have insignificant relationship with stock prices in India.

Table 3. Granger Causality Test, January 2000 - February 2012

\begin{tabular}{|c|c|c|c|}
\hline \multirow[t]{2}{*}{ Null Hypothesis: } & $\begin{array}{l}\text { Standard Granger } \\
\text { causality test }\end{array}$ & $\begin{array}{l}\text { Granger causality } \\
\text { test based on VECM }\end{array}$ & \multirow[t]{2}{*}{ Null Hypothesis: } \\
\hline & F-Statistic & Chi-sq & \\
\hline GRSP $\neq>$ GRIR & 5.27995 & 27.51147 & FRIR $\neq>$ FRSP \\
\hline AUSP $\ddagger>$ AUIR & 5.89158 & 18.50202 & FIIR $\neq>$ FISP \\
\hline BESP $\ddagger>$ BEIR & 10.2227 & 8.722366 & ITSP $\neq>$ ITIR \\
\hline CYSP $\neq>$ CYIR & 9.72795 & 35.32730 & ITIR $\ddagger>$ ITSP \\
\hline DKSP $\ddagger>$ DKIR & 4.30451 & & \\
\hline DESP $\neq>$ DEIR & 4.45267 & & \\
\hline DEIR ‡> DESP & 2.91419 & & \\
\hline GBSP $\neq>$ GBIR & 5.83088 & & \\
\hline IESP $\neq>$ IEIR & 7.71785 & & \\
\hline LUSP $\ddagger>$ LUIR & 10.2754 & & \\
\hline PTSP $\neq>$ PTIR & 4.27622 & & \\
\hline CZSP $\neq>$ CZIR & 3.61266 & & \\
\hline SISP $\neq>$ SIIR & 3.81951 & & \\
\hline ESSP $\neq>$ ESIR & 3.91879 & & \\
\hline SESP $\neq>$ SEIR & 3.66515 & & \\
\hline SEIR $\ddagger>$ SESP & 8.34399 & & \\
\hline EESP $\ddagger>$ EEIR & 5.45165 & & \\
\hline EEIR ‡> EESP & 4.08711 & & \\
\hline
\end{tabular}


Table 4. Granger Causality Test, July 2007 - February 2012

\begin{tabular}{|c|c|c|c|}
\hline \multirow[t]{2}{*}{ Null Hypothesis: } & $\begin{array}{l}\text { Standard Granger } \\
\text { causality test }\end{array}$ & $\begin{array}{l}\text { Granger causality test } \\
\text { based on VECM }\end{array}$ & \multirow[t]{2}{*}{ Null Hypothesis: } \\
\hline & F-Statistic & Chi-sq & \\
\hline GRSP $\neq>$ GRIR & 3.91627 & 7.518996 & BEIR $\ddagger>$ BESP \\
\hline ROIR ‡> ROSP & 10.2227 & 46.56603 & BESP $\neq>$ BEIR \\
\hline CYIR $\neq>$ CYSP & 9.63955 & 18.30410 & DKSP $\ddagger>$ DKIR \\
\hline DESP $\neq>$ DEIR & 5.92677 & 4.45267 & FRIR $\ddagger>$ FRSP \\
\hline CZSP $\neq>$ CZIR & 6.37657 & 7.518429 & FISP $\neq>$ FIIR \\
\hline \multirow[t]{6}{*}{ ESSP $\neq>$ ESIR } & 5.36598 & 47.09475 & GBIR ‡> GBSP \\
\hline & & 4.046494 & IESP $\neq>$ IEIR \\
\hline & & 3.156752 & LUSP $\ddagger>$ LUIR \\
\hline & & 5.430297 & PTSP $\ddagger>$ PTIR \\
\hline & & 22.97616 & LVSP $\ddagger>$ LVIR \\
\hline & & 30.59817 & LVIR $\ddagger>$ LVSP \\
\hline
\end{tabular}

The results from the subsample presented in Table 4 suggest that on the short-run the comovement between stock and money markets is lower during the crisis periods than during the entire analyzed period. This findings suggest that on the short term the stock market and the money market might be influenced by other factors like external shocks or investors' uncertainty,

\section{Conclusion}

This study has investigated the comovement between interest rates and stock prices in EU markets. Using Johansen and Granger causality tests for the period January 2000 to February 2012, the study documented both short-run and long-run interdependence among stock index and interest rates. Employing Johansen co-integration analysis, we found that over the entire period, the long-term relationship does exist between the two variables only in the cases of Netherlands, France, Finland and Italy. However, when we took into consideration the crisis period, the situation was different, highlighting the fact that this dynamics exist amongst the two variables in twenty countries from a total of twenty seven. These results might be due to the contagion or spillover between the two variables during the crisis and to the investors' uncertainty regarding the unfavorable macroeconomic environment. Also, before the crisis, the central banks based their monetary policy projections on a short horizon, disregarding the financial imbalances which are built on a much longer time. Given the actual crisis, the political economy has received a warning with respect to this mismatch, therefore is trying to harmonize both, monetary policy and financial stability policy.

In the short-run, the direction of causation over the entire sample is bi-directional for Germany, Sweden, France, Italy and Estonia, is unidirectional from the stock to the money market for the Greece, Austria, Belgium, Cyprus, Denmark, United Kingdom, Ireland, Luxembourg, Portugal, Czech Republic, Slovenia and Spain, and is non-causal for Netherlands, Romania, Hungary, Malta, Bulgaria, Finland, Lithuania, Latvia, Poland and Slovakia. Moreover, the findings regarding the two variables during the crisis suggest there exist a smaller number of markets that register a causal relationship between interest rates and stock index. These results might be due to the existence of more important factors that affect the stock market on the short-run, like uncertainty among investors and external shocks.

The limits of our paper consist in the fact that we took into consideration low frequency index, i.e. monthly, meaning the fact that we didn't incorporate all the changes that occurred during the month. Moreover, we might consider as a proxy variable for the monetary policy other variables as inflation 
rate, regarding the fact that the literature emphasis the direct relation between inflation and stocks.

For future research it would be interesting to analyse the impact of key interest rate (proxy variable for monetary stability) on market interest rates, nominal exchange rate, stock index, loan / deposit ratio (proxy variable for financial stability).

\section{Acknowledgement}

This work was supported by the project "Post-Doctoral Studies in Economics: training program for elite researchers - SPODE" cofunded from the European Social Fund through the Development of Human Resources Operational Programme 20072013, contract no. POSDRU/89/1.5/S/61755.

\section{References}

Adam, A. M. \& Tweneboah, G. (2008). "Do Macroeconomic Variables Play Any Role in the Stock Market Movement in Ghana?," [Online] MPRA. Paper No. 9357. [03.02.2012]. Available:

http://mpra.ub.uni-

muenchen.de/9357/1/MPRA_paper_9357.pd f

Alagidede, P., Panagiotidis, T. \& Zhang, X. (2011). "Causal Relation between Stock Prices and Exchange Rate," The Journal of International Trade \& Economic Development, 20 (1), 67-86.

Anderson, M. (2010). "Using Intraday Data to Gauge Financial Market Response to Federal Reserve and ECB Monetary Policy Decision," International Journal of Central Banking, 6(2), 117 - 16.

Assenmacher-Wesche, K. \& Gerlach, S. (2008). "Can Monetary Policy Really Be Used to Stabilize Asset Prices?," Institute for Monetary and Financial Stability Working Paper No. 16, University of Frankfurt.
Bjornland, H. C. \& Leitemo, K. (2009). "Identifying the Interdependence between US Monetary Policy and Stock Market," Journal of Monetary Economics, 56, 275-282.

Bohl, M. T., Siklos, P. L. \& Werner, T. (2007). "Do Central Banks React to the Stock Market? The case of the Bundesbank", Journal of Banking \& Finance, 31, 719-733.

Bordo, M. D. \& Jeanne, O. (2002). “Monetary Policy and Asset Prices: Does "Benign Neglect" Make Sense?," International Finance, 4, 139-164.

Bredin, D., Hyde, S., Nitzsche, D. \& O’Reilly, G. (2007). "UK Stock Returns and the Impact of Domestic Monetary Policy Shocks," Journal of Business Finance \& Accounting 34, 872-888.

Bullard, J. B. \& Schaling, E. (2002). "Why the Fed should Ignore the Stock Market," Federal Reserve Bank of St. Louis Review, 84 (2), 3542.

Cassola, N. \& Morana, C. (2004). "Monetary Policy and the Stock Market in the Euro Area," Journal of Policy Modeling, 26, 387399.

Corallo, E. (2006). The Effect of Monetary Policy on Asset Prices: Evidence from Germany and U.K., Cattaneo University (LIUC) Papers in Economics No.185.

Farka, M. (2009). "The Effect of Monetary Policy Shocks on Stock Prices Accounting for Endogeneity and Omitted Variable Biases," Review of Financial Economics 18, 47-55.

Granville, B. \& Mallick, S. (2009). "Monetary and Financial Stability in the Euro Area: ProCyclicality Versus Trade-Off," Journal of International Financial Markets, Institutions \& Money 19, 662-674. 
Hunter, W. C., Kaufman, G. G. \& Pomerleano, M. (2005). Asset Price Bubbles: The Implications for Monetary, Regulatory and International Policies, MIT press, London, England.

Hussain, S. M. (2010). "Simultaneous Monetary Policy Announcements and International Stock Markets Response: An Intraday Analysis," Bank of Finland Research Discussion Paper No. 8/2010.

Illing, G. (2006). 'Financial Stability and Monetary Policy - A Framework,' CESifo Working Paper Series, No. 1971.

Ioannidis, C. \& Kontonikas, A. (2008). "The Impact of Monetary Policy on Stock Prices,",Journal of Policy Modeling, 30, 33-53.

Jansen, D. W. \& Tsai, C.- L. (2010). “Monetary Policy and Stock Returns: Financing Constraints and Asymmetries in Bull and Bear Markets," Journal of Empirical Finance, 17, 981-990.

Joshi, N. K. \& Bhattarai, R. C. (2009). "Dynamic Relationship among the Stock Market and the Macroeconomic Factors: Evidence from Nepal," South Asia Economic Journal, 10 (2), 2009, 451-469.

Kaul, G. (1987). "Stock Returns and Inflation The Role of the Monetary Sector," Journal of Financial Economics, 18(2), 253-276.

Kholodilin, K., Montagnoli, A., Napolitano, 0. \& Siliverstovs, B. (2009). "Assessing the Impact of ECB's Monetary Policy on the Stock Markets: A Sectoral View," Economics Letters, Elsevier, 105(3), 211-213.

Konrad, E. (2009). "The Impact of Monetary Policy Surprises on Asset Return Volatility: The Case of Germany," Financial Markets and Portfolio Management, 23, 111-135.
Korkeamäki, T. (2011). "Interest Rate Sensitivity of the European Stock Markets Before and After the Euro Introduction," Journal of International Financial Markets, Institutions \& Money, 21, 811- 831.

Lin, C.- H. (2012). "The Comovement between Exchange Rates and Stock Prices in the Asian Emerging Markets," Journal of International Review of Economics and Finance, 22(1), 161172.

Li, Y. D., Işcan, T. B. \& Xu, K. (2010). “The Impact of Monetary Policy Shocks on Stock Prices: Evidence from Canada and the United States," Journal of International Money and Finance, 29, 876-896.

Pal, K. \& Mittal, R. (2011). "Impact of Macroeconomic Indicators on Indian Capital Markets," The Journal of Risk Finance, 12(2), 84 - 97.

Pennings, S., Ramayandi, A. \& Tang, H. C. (2011). "The Impact of Monetary Policy on Financial Markets in Small Open Economies: More or Less Effective during the Global Financial Crisis?," ABD Working Paper Series on Regional Economic Integration, Asian Development Bank, No. 72.

Rigobon, R. \& Sack, B. (2004). "The Impact of Monetary Policy on Asset Prices," Journal of Monetary Economics, Elsevier , 51(8), 15531575.

Vithessonthi, C. \& Techarongrojwong, Y. (2012). "The Impact of Monetary Policy Decisions on Stock Returns: Evidence from Thailand," Journal of International Financial Markets, Institutions \& Money 22, 487- 507.

Wouter Botzen, W. J. \& Marey, P. S. (2010). "Did the ECB Respond to the Stock Market Before the Crisis?," Journal of Policy Modeling, 32, 303-322. 


\section{Appendix A}

Table A1. Optimal Lag Length between Interest Rate and Stock Prices - Akaike Information Criterion

\begin{tabular}{|c|c|c|}
\hline Countries & $\begin{array}{l}\text { January } 2000-\text { February } \\
2012\end{array}$ & July 2007 - February 2012 \\
\hline Netherlands & 2 & 1 \\
\hline Greece & 4 & 2 \\
\hline Austria & 2 & 1 \\
\hline Belgium & 2 & 1 \\
\hline Romania & 7 & 5 \\
\hline Hungary & 2 & 2 \\
\hline Cyprus & 2 & 2 \\
\hline Denmark & 4 & 1 \\
\hline Germany & 3 & 2 \\
\hline France & 2 & 2 \\
\hline United Kingdom & 4 & 1 \\
\hline Finland & 3 & 2 \\
\hline Ireland & 2 & 1 \\
\hline Italy & 2 & 2 \\
\hline Luxembourg & 2 & 1 \\
\hline Malta & 2 & 3 \\
\hline Portugal & 6 & 2 \\
\hline Czech Republic & 4 & 4 \\
\hline Latvia & 3 & 1 \\
\hline Slovakia & 2 & 2 \\
\hline Slovenia & 2 & 2 \\
\hline Bulgaria & 2 & 2 \\
\hline Spain & 3 & 2 \\
\hline Sweden & 2 & 1 \\
\hline Estonia & 2 & 2 \\
\hline Lithuania & 5 & 2 \\
\hline Poland & 6 & 3 \\
\hline
\end{tabular}

